JOURNAL OF TOURISM AND SERVICES

Issue 20, volume 11, ISSN 1804-5650 (Online)

www.jots.cz

\title{
Evaluation of the Impact of Sharing Economy on Hotel Business
}

\author{
Paulína Srovnalíková \\ Alexander Dubček University of Trenčín, Trenčín, Slovakia \\ Evelina Semionovaitė \\ UAB KPMG Baltics, Klaipèda, Lithuania \\ Edita Baranskaitè \\ Klaipèda University, Klaipèda, Lithuania \\ Daiva Labanauskaitè \\ Klaipeda University, Klaipeda, Lithuania
}

Received: 20 April 2020. Revision received: 28 May 2020. Accepted: 7 June 2020

\begin{abstract}
The sharing economy is growing in the hotel industry very fast. The study is important for the hotel's management - strategy formulation. The aim of this research is to evaluate the sharing economy effect on hotels in Lithuania. Correlation and regression analysis methods were used for achieving the aim. The study analyses if the sharing economy has caused any impact on accommodating tourists at hotels, hotels income from accommodation services, and room occupancy rate. Results reveal a positive relationship between the sharing economy and all investigated indicators of hotel activities, thus indicating that the hotel business is growing together with the sharing economy. The hotels' sector in Lithuania has continued to grow while more and more hosts and consumers joined the sharing economy. Results imply that the sharing economy is not a competitor for the Lithuanian hotels business as the sharing economy targets different tourist segment, moreover the market is capacious for both segments. Sharing economy in the accommodation sector - a niche with its own customer group. The research results are important for making correct decisions in the Lithuanian tourism industry as other researches in other countries show a negative impact on the sharing economy on the hotels' sector. The rapid growth of the sharing economy in Lithuania may oblige hotels to focus on the sharing economy and consider further actions.
\end{abstract}

Key words: sharing economy, sharing economy in tourism, sharing economy economic impact, sharing economy impact on hotels business.

JEL Classification: P14, P19, Z19.

Reference: Srovnalíková, P., Semionovaitè, E., Baranskaitè, E., Labanauskaitè, D. (2020). Evaluation of the Impact of Sharing Economy on Hotel Business. Journal of Tourism and Services, 20(11), 150-169. doi: 10.29036/jots.v11i20.145.

\section{Introduction}

For many years people tended to use only the things belonging to them, but nowadays due to changing economic, social, and technological conditions more and more consumers are looking for renting and sharing items rather than owning them. Technology development, online platforms enabled connections between people, changed the way people communicate and interact in today's world. These changes have led to the rapid growth of the sharing economy worldwide.

Recent research (Muñoz \& Cohen, 2018) has shown that by 2015 start-ups in the sharing economy business have raised more than $\$ 15$ billion in venture capital, the top seventeen sharing 


\section{JOURNAL OF TOURISM AND SERVICES}

Issue X, volume X, ISSN 1804-5650 (Online)

www.jots.cz

companies are worth more than $\$ 1$ billion each and have more than 60,000 employees. PricewaterhouseCoopers (2015) predicts that by 2025 global revenues from the sharing economy will increase from $\$ 15$ billion in five sectors (travel, car sharing, finance, staffing and music and video streaming) up to $\$ 335$ billion dollars. According to the study (Muñoz, Cohen, 2018), the sharing economy is growing faster than Facebook, Google, and Yahoo together. This demonstrates that the sharing economy has emerged rapidly as a major and growing force that can affect the traditional economy.

The sharing economy appears in many sectors, but this phenomenon has a major impact in the hospitality industry. The Internet has affected the tourism industry a lot by transforming the classic tourism business into online platforms (Ključnikov et al., 2020; Jibril et al., 2019). There is an increase of discussions in the literature about the sharing economy, its benefits, threats, and implications for the traditional economy. The economic impact is different in different sectors. K. Barron, E. Kung, and D. Proserpio (2018) explored the impact of home sharing on the long-term rental market using all the US rental listings on the Airbnb platform. The results show that the opportunity to "share" homes has led to higher rental and housing prices. With a 1\% increase of Airbnb deals, rents are up $0.018 \%$ and home purchase prices are up $0.026 \%$. While S. Brauckmann (2017) explored the potential impact of the sharing economy on increasing number of tourists in the city of Hamburg and the real estate market in this city. The results revealed that new hotels are being built mainly in downtown commercial areas, while Airbnb offers are primarily found in areas popular as alternative residential areas near the city center. This creates a competitive situation that can lead to higher real estate prices and rents. However, there is no research on the sharing economy in Lithuania. Only briefly this issue is analysed in the cluster-forming counterexample (Navickas et al., 2017).

The problem: the impact of the sharing economy on the Lithuanian hotel business is unknown.

Assessing the impact of the sharing economy on the Lithuanian hotel business can have a significant impact on hotels' strategic decisions.

The object of the article - the impact of the sharing economy on the hotels business in Lithuania.

The aim of the article - to evaluate the impact of the sharing economy on the Lithuanian hotels business.

Tasks:

1. To systematize the theoretical aspects of the sharing economy concept.

2. To overview hotel business specifics in the context of the sharing economy.

3. To assess the impact of the sharing economy on hotels business in Lithuania.

Methods: analysis of scientific literature, statistical data analysis, correlation and regression methods using statistical data processing software - SPSS.

\section{Literature Review on Theoretical Aspects of Sharing Economy}

\subsection{The Concept of the Sharing Economy Driven by Innovation}

The sharing economy is a relatively new phenomenon that has become an interesting topic for researchers, but there is no single generally accepted, comprehensive definition in the literature (Grybaite, \& Stankevičienè, 2018).

One of the terms that is used as a sharing economy is general consumption. It is defined as an economic opportunity for individuals to exchange their underutilized assets with others through information technology intermediaries, effectively matching supply and demand (Petropoulos, 2017). It is an economic activity that works through technology (Alaerds, Grove, 2017; Androniceanu, 2019). The companies in the sharing economy have not created radical new tools to meet the needs of consumers, they only provide information that makes it easier for people to find what they are looking for or do what they want to do around the world (Skackauskiene et al., 2015; Wierzbicka, 2018). According to T. Kasprowicz (2016), the sharing economy needs to be understood as an online marketplace for renting 


\section{JOURNAL OF TOURISM AND SERVICES}

Issue X, volume X, ISSN 1804-5650 (Online)

www.jots.cz

physical assets, money, services, using user-to-user channels. A lot of authors have similar approaches in defining the concept (table 1).

Table 1. Definitions of the sharing economy

\begin{tabular}{|l|l|}
\hline \multicolumn{1}{|c|}{ Author } & Definition \\
\hline R. Botsman, 2015 & $\begin{array}{l}\text { The sharing economy - systems that facilitate the sharing of scarce assets or services, } \\
\text { either free of charge or directly between individuals or organizations. }\end{array}$ \\
\hline S. Das, 2018 & $\begin{array}{l}\text { The sharing economy is a mediation service that brings together users and providers } \\
\text { of services or goods. Platforms create virtual electronic markets using broadband } \\
\text { internet, smartphones, and applications. This allows buyers and sellers to complete } \\
\text { the exchange. }\end{array}$ \\
\hline $\begin{array}{l}\text { A. Felländer, } \\
\text { C. Ingram, } \\
\text { R. Teigland, 2015 }\end{array}$ & $\begin{array}{l}\text { The sharing economy involves the exchange of tangible and intangible resources } \\
\text { including information in a global and local context. }\end{array}$ \\
\hline $\begin{array}{l}\text { A. Bergh, } \\
\text { A. Funcke, } \\
\text { J. Wernberg, } \\
2018\end{array}$ & $\begin{array}{l}\text { The sharing economy service is a platform that facilitates transactions between } \\
\text { identifiable service providers and identifiable customers who need these services. The } \\
\text { transaction cannot involve a transfer of ownership and is done on a case-by-case } \\
\text { basis where neither party is required to make future transactions. }\end{array}$ \\
\hline
\end{tabular}

The common aspects in reviewed definitions are: the sharing economy uses a consumer-toconsumer business model where demand and supply are matched through a digital platform, created and operated by a third party.

\subsection{The Features of the Sharing Economy}

The main tool for understanding the sharing economy is to analyse its features functioning processes (Henten \& Windekilde, 2016).

The key features of the sharing economy are:

Access instead of ownership. Consumers' attitudes and behaviours are shifting from high consumerism and preference for goods to purchasing access to goods.

User-to-user. Internet-based networks and platforms are mediating and coordinating with consumers through trust relationships and personal reputations.

Allocation of idle resources. More and more individuals are voluntarily engaging in economic activity, drawing on private resources (both assets and labour) that would otherwise remain unused (Constantiou, Marton \& Tuunainen, 2017).

D. Šmskis (2016) and L. Mura et al. (2018) argue that the sharing economy is characterized by a specific type of business model where an online platform allows buyers and sellers to communicate directly. Digital platforms typically provide a variety of tools, such as online connectivity, feedback, payment systems, etc., which improves the process of creating new values (Ciarniene et al., 2017). According to T. Kasprowicz (2016), the sharing economy needs to be understood as an online marketplace for renting physical assets, money, services, using user-to-user channels. Sharing economy platforms act as intermediaries for a fee (Constantiou et al., 2017). By doing so, they reduce risk, increase participant confidence, and reduce transaction costs for their platform users (Nosková \& Peráček, 2019; Anyakoha, 2019). This mediated exchange system reduces transaction costs for consumers by replacing third-party intermediaries with digital platforms (Felländer et al., 2015). Sharing economy characterizing model is presented as Figure 1.

The sharing economy is characterized by managing and matching supply and demand, providing faster and more convenient services. 
JOURNAL OF TOURISM AND SERVICES

Issue X, volume X, ISSN 1804-5650 (Online)

www.jots.cz

Figure 1. Sharing economy model. Source: Authors

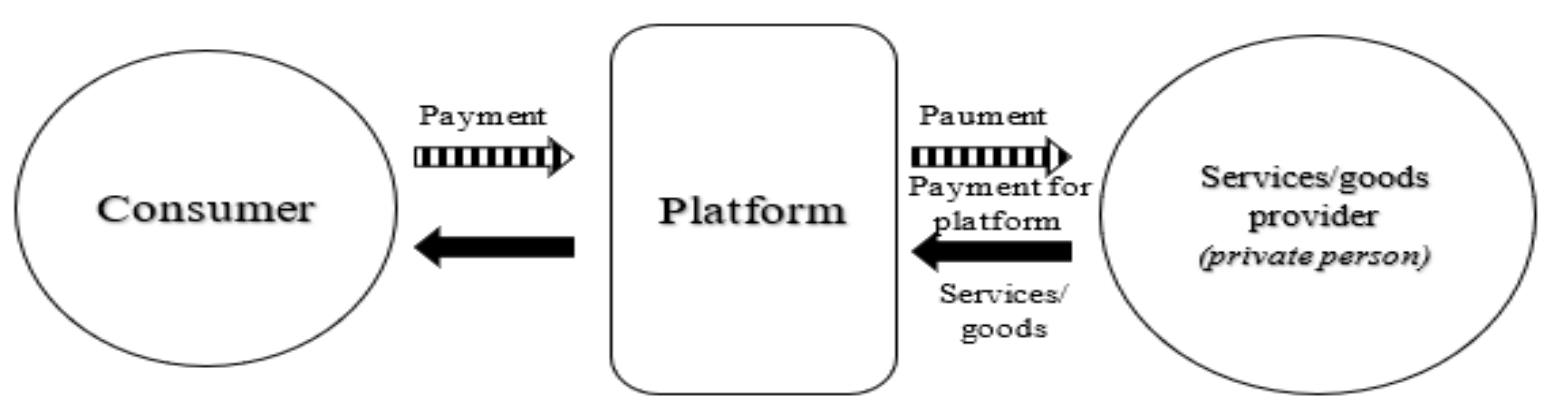

Source: own collaboration.

\subsection{The Impact of Sharing Economy to the Market}

According to the Lithuanian Competition Council (2016), the sharing economy provides greater diversity of services, more choice for consumers, and higher quality services at a better price.

There are also more benefits. It increases competition leading to lower prices, active entrepreneurship, and higher households' income (Ključnikov et al., 2019). According to Deloitte economists M. Grampp, L. Zobrist \& A. Abegg (2016), goods and services in the sharing economy can be exchanged with people from all over the world in a few clicks. This may result in market transactions that would not have occurred previously due to the excessive costs of the related transactions.

S. Bhise \& R. K. Singh (2016) have noted that the sharing economy has also increased people's employability. This phenomenon has paved the way for self-employment, more people are becoming entrepreneurs (Mészáros, 2018; Dkhili, 2018; Vasylieva et al., 2017).

Sharing economy increases sustainability (Androniceanu \& Tvaronavičiené, 2019). It is estimated that one US city bicycle sharing scheme replaced $41 \%$ of car trips (Denver Bike Sharing, 2017), with Airbnb guests consuming 78\% less energy and water than hotel guests (Airbnb, 2014). It is also believed that car sharing reduces the number of vehicles on the roads (Ranchordás, 2016).

Another sharing economy effect is the use of public resources and public expenditure (Ranchordás, 2016). For example, some US municipalities lend trucks and heavy equipment to each other using the MuniRent platform (MuniRent, 2019), one London township has converted its employee cars into a Zipcar partnership, reducing staff travel expenses by as much as 40\% (Zipcar, 2013). In the age of budget austerity, such savings and efficiency cannot be overstated.

It can be said that the sharing economy has a positive impact on various areas: economy, market, society, consumers, service quality. By removing barriers to ownership and improving access to goods and services, the sharing economy has a positive impact on low-income people. Sharing the economy has a positive impact on communities by strengthening local economies, living standards, basic infrastructure, entrepreneurship opportunities and social relationships (Jašková, 2019).

Some authors (Malhotra \& Van Alstyne, 2014; Biswas, Pahwa \& Sheth, 2015) point out that while the sharing economy offers many benefits, its rapid growth also presents challenges such as trust and security.

The sharing economy, like any other phenomenon, has its advantages and disadvantages. Advantages include more transactions, bigger variety, lower prices, higher income, employment, and sustainability. While disadvantages include trust issues and safety.

In this context, Belas at al. (2020) in their empirical case study showed that business ethics is considered extremely important in the business environment in the Czech and Slovak Republic. Their research results not only revealed that just over $90 \%$ of Czech entrepreneurs and $88 \%$ of Slovak entrepreneurs within the SME sector agreed that they should take into account the moral and ethical consequences of their decisions. 


\section{JOURNAL OF TOURISM AND SERVICES}

Issue X, volume X, ISSN 1804-5650 (Online)

www.jots.cz

\subsection{Hotel Business in the Context of Sharing Economy}

Digital platforms are changing the way the tourism industry operates, affecting destination tourism, data collection, market access and visitor attraction. The scale of the sharing economy in accommodation sector is huge. For example, one of the most well-known platforms Airbnb has more than 70 million visitors, over 2 million listings and the total number of Airbnb covered cities is 34,000 (Chafkin, 2016).

The key factors driving the growth of accommodation services in the sharing economy are (The World Bank Group, 2018):

- Increasing number of travellers. Some time ago traveling was a luxury activity, now it is considered as a necessity (Mura \& Kajzar, 2019). More and more people are traveling for business, entertainment, education, health, sports, and family than ever before. This means the bigger demand for accommodation to meet the traveller's needs.

- Cheap airlines allow a much wider socio-economic group to travel. Cheap carriers allowed lower- and middle-income consumers, larger families, and groups to travel. These travellers are more diverse than ever and are not interested in standard hotel rooms.

- Digital technology has reduced search, booking, tracking and verification costs when booking accommodation. Lower search costs make finding of niche products and unknown products easier. Lower costs for identity and reputation verification allow transactions with unknown providers.

- The growing interest in more authentic traveller experiences is creating the need for unconventional accommodation and closer links with host communities.

According to the World Bank Group (2018), the sharing economy has various advantages in the accommodation sector. It primarily promotes the development of tourism products. For example, sharing economy accommodation can help attract new market segments to existing and new destinations.

The sharing economy also changes the behaviour of guests. Tourists are more open to independent holidays and seek more information from other tourists (friends, family or anonymous tourists who post reviews online) than before. Many tourists use digital technology and social networks to plan, purchase or review travel experiences (OECD, 2018; Oskam \& Boswijk, 2016).

Hotel industry is affected by the sharing economy trends. Sharing economy not only occupies the bigger market share but also helps to grow the industry by attracting new customers, shaping the tourist behaviour.

\section{Methods}

The evaluation of the impact of the sharing economy on Lithuanian hotel business is based on statistical indicators. The analysis of statistical indicators helps to identify value changes over the time.

The hotel business economic performance is determined by the number of customers, rooms occupancy and revenue. The aim of the research is to identify if the sharing economy has a link with Lithuanian hotel business key performance indicators (KPIs): number of customers, rooms occupancy and revenue. The sharing economy variables used in the research: private accommodation customers, number of nights, number of suppliers, private accommodation income. In this case correlation and regression methods are chosen to identify if there is a link between the sharing economy popularity and hotel business KPIs as in most researches correlation and regression analysis methods are used to determine the relationship between variables. It is important to note that the number of tourists is different every year. The growth of tourists may increase the growth of both sharing economy and traditional hotel businesses. However, if sharing economy impacts on hotel business, both sectors growth would be different and correlation, regression analyses by using SPSS software would identify the link.

Correlation analysis determines whether there is a relationship between the factors. Correlation describes the direction and strength of the relationship between the two variables. The direction may be positive or negative: a positive correlation - an increase in one variable is associated with an increase in 


\section{JOURNAL OF TOURISM AND SERVICES}

Issue X, volume X, ISSN 1804-5650 (Online)

www.jots.cz

another variable, a negative correlation - an increase in one variable is associated with a decrease in other variables (Greasley, 2008). Absolute value of correlation coefficient (Bekešiené, 2015):

- 0 to 0.2 - very weak correlation (no relationship);

- 0.2 to 0.4 - weak correlation (weak connection);

- 0.4 to 0.7 - average correlation (mean relationship);

- 0.7 to 0.9 - strong correlation (strong relationship);

- More than 0.9 - very strong correlation.

Regression analysis is used after calculating the correlation coefficient and identifying the relationship between the variables. It allows to identify the influence of factors on the economic phenomenon under consideration in a mathematical equation (Mikołajczak, 2019). Regression analysis determines the nature of the statistical relationship and describes the dependence of the mean values of the dependent (consequence) variable on one or more independent (cause) variables in a mathematical formula and simultaneously predicts the values of this variable. Main data requirements for regression analysis (Čekanavičius \& Murauskas, 2014; Kiseláková et al., 2019):

- The dependent variable $\mathrm{Y}$ is normally distributed. The closer regressors are to the normal random variables, the better it fits to the model.

- All other variables are interval based.

- There should be no exclusions in the data.

Validity of linear regression model (Čekanavičius \& Murauskas, 2014):

- Coefficient of determination (R2). This is the most important characteristic of the model's credibility to the data. The coefficient of determination acquires values from the interval $[0,1]$. The higher the coefficient value, the better the model fits into the data. It is bad when $\mathrm{R} 2<0.20$.

- ANOVA $\mathrm{p}$ value. It indicates whether the model has regressors related to the dependent variable. If the $\mathrm{p}$ value is greater than 0.05 , then the fit of the regression model is highly questionable. If the $\mathrm{p}$ value is less than 0.05 , then the model is valid.

The data for the research - private tourist accommodation indicators (number of nights at private tourist accommodation, number of tourists accommodated in private accommodation, income of private accommodation, number of private accommodation providers, number of private accommodation establishments). Private tourist accommodation is a type of accommodation where private persons hold a business license or a certificate of self-employment to provide short-term accommodation (Statistics Lithuania, 2018). This data is selected as the most suitable for representing the sharing economy accommodation sector in Lithuania. Year 2012-2018 monthly data used for correlation and linear regression analysis.

Hypotheses:

H1: The sharing economy growth has a negative impact on the number of tourists staying at hotel.

H2: The sharing economy growth has a negative impact on hotels business revenue from accommodation services.

H3: The sharing economy growth has a negative impact on hotel room occupancy.

\section{Results}

Since 2012 the number of tourists at accommodation establishments in Lithuania is steadily increasing (80.11\% growth). The growth is in both private accommodation and hotels (Fig. 2). However, the growth of tourists was much lower in hotels than in sharing economy establishments. The number of tourists increased in hotels by $70.89 \%$ while the number of tourists in private accommodation increased by $233.21 \%$. However, the absolute values prove that hotels business is still dominant. Despite the huge growth, the sharing economy increased market share only by $4.83 \%$. 
JOURNAL OF TOURISM AND SERVICES

Issue X, volume X, ISSN 1804-5650 (Online)

www.jots.cz

Figure 2. Number of tourists at hotels and private accommodations in Lithuania in 2012-2019, Source: Statistics Lithuania

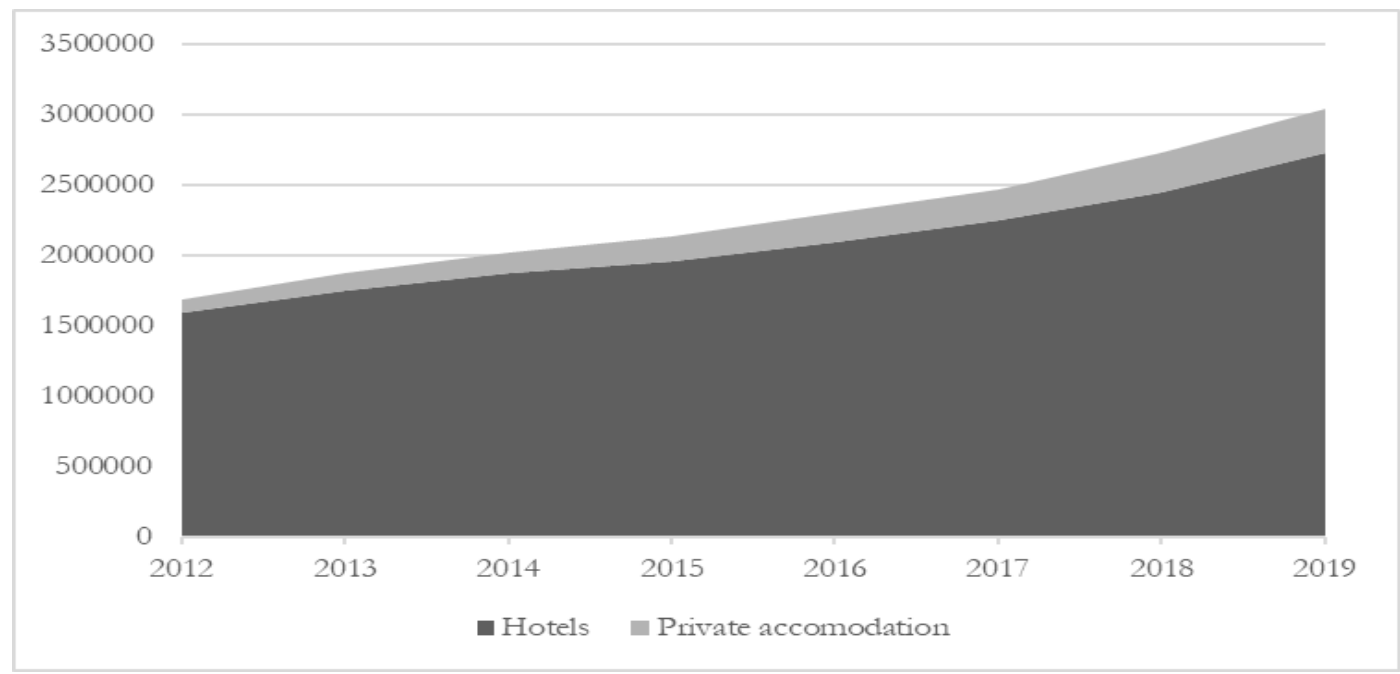

Source: own collaboration.

The total accommodation business revenue increased much faster than the number of tourists. Total revenue increased by $131.3 \%$ (Fig. 3). Hotels revenue growth was much lower than private accommodation revenue growth. Hotels revenue growth $-116.64 \%$, private accommodation revenue growth $-388.59 \%$.

It implies the fact that during 2012-2019 there was a growth in Lithuanian accommodation sector. However, the sharing economy (private accommodation) is growing much faster than the hotels business, the dynamics of the hotel business and the sharing economy are different. Analysed trends do not reveal if the private accommodation market share growth is affecting hotels business growth or it is growing independently. To analyse it, correlation and regression analyses are presented further.

Figure 3. Revenue of hotels and private accommodations in Lithuania in 2012-2019, Source: Statistics Lithuania

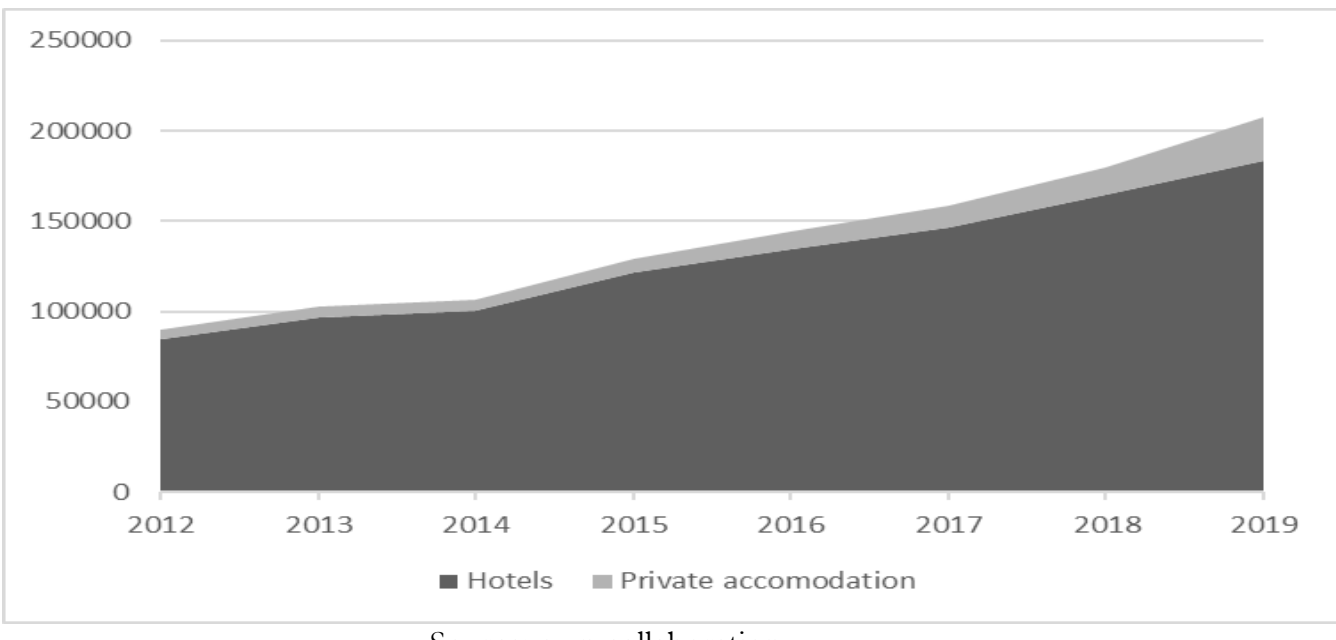

Source: own collaboration.

Analysis of the asymmetry and excision coefficients reveals that the closest to the normal distribution is the number of tourists staying at hotels variable (Table 2). The coefficients of the other two variables are far from zero that they may be considered to have an abnormal distribution. There are many exclusions in these samples. 
JOURNAL OF TOURISM AND SERVICES

Issue X, volume X, ISSN 1804-5650 (Online)

www.jots.cz

Table 2. Asymmetry and excision coefficients for annual data

\begin{tabular}{|l|c|c|}
\hline & Skewness & Kurtosis \\
\hline Number of tourists staying at hotels & 0.460 & -0.450 \\
\hline Private tourist accommodation provided overnight stays. & 1.892 & 2.840 \\
\hline Number of tourists at private tourist accommodation & 1.876 & 3.011 \\
\hline
\end{tabular}

Source: own collaboration.

Statistical studies are susceptible to exceptions, so exceptions should be excluded from the study to avoid distortion of study results. After removing the exceptions, the asymmetry and excision coefficients of these data are shown in Table 3. According to Darren George and Paul Mallery (2010), the values of these coefficients between -2 and +2 are also acceptable for the normality of the data.

Table 3. Asymmetry and excision coefficients after exclusion (annual data)

\begin{tabular}{|l|c|c|}
\hline & Skewness & Kurtosis \\
\hline Private tourist accommodation provided overnight stays. & 1.633 & 1.994 \\
\hline Number of tourists in private tourist accommodation & 1.411 & 1.530 \\
\hline
\end{tabular}

Source: own collaboration.

The condition of data normality was also verified by Kolmogorov-Smirnov test (Table 4). The number of tourists staying at hotels variable has a p-value greater than 0.05 , the assumption of normality cannot be ruled out. Although this test shows an abnormal distribution of the remaining two variables $(\mathrm{p}$ $<0.05)$, they will be used in regression analysis based on the asymmetry and excision coefficients.

Correlation analysis revealed (Table 5) that all variables correlated statistically significantly ( $p$ $<0.05)$. The number of tourists staying in hotels is positively correlated $(r>0.7)$ with both variables, making them a good fit for the regression model.

Table 4. Kolmogorov-Smirnov test (annual data)

\begin{tabular}{|l|c|c|c|}
\hline \multirow{2}{*}{} & \multicolumn{3}{|c|}{ Kolmogorov-Smirnov } \\
\cline { 2 - 4 } & Statistic & $\mathrm{df}$ & $\mathrm{p}$ \\
\hline Number of tourists staying at hotels & 0.073 & 73 & 0.200 \\
\hline Private tourist accommodation provided overnight stays. & 0.224 & 73 & 0.000 \\
\hline Number of tourists in private tourist accommodation & 0.185 & 73 & 0.000 \\
\hline
\end{tabular}

Source: own collaboration.

Table 5. Correlation between the number of hotel tourists and the regressors (annual data)

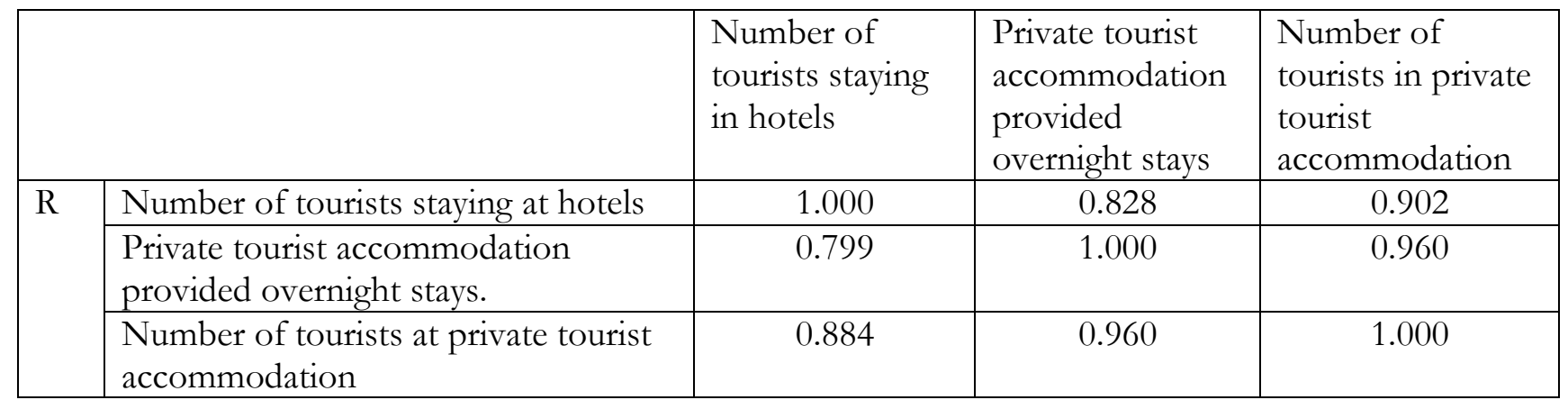


JOURNAL OF TOURISM AND SERVICES

Issue X, volume X, ISSN 1804-5650 (Online)

www.jots.cz

\begin{tabular}{|l|l|c|c|c|}
\hline $\mathrm{P}$ & Number of tourists staying at hotels &. & 0.000 & 0.000 \\
\cline { 2 - 5 } & $\begin{array}{l}\text { Private tourist accommodation } \\
\text { provided overnight stays. }\end{array}$ & 0.000 & $\cdot$ & 0.000 \\
\cline { 2 - 5 } & $\begin{array}{l}\text { Number of tourists at private tourist } \\
\text { accommodation }\end{array}$ & 0.000 & 0.000 & $\cdot$ \\
\hline
\end{tabular}

Source: own collaboration.

Although the correlation does not show a causal link, the positive correlation coefficients between the number of tourists staying at hotels and the number of overnight stays provided by private tourists show that the sharing economy does not negatively affect the number of tourists staying at Lithuanian hotels.

The results of the regression analysis are shown in Figures 4 and 5.

Figure 4. Linear regression graph of hotel tourists and private accommodation (monthly data)

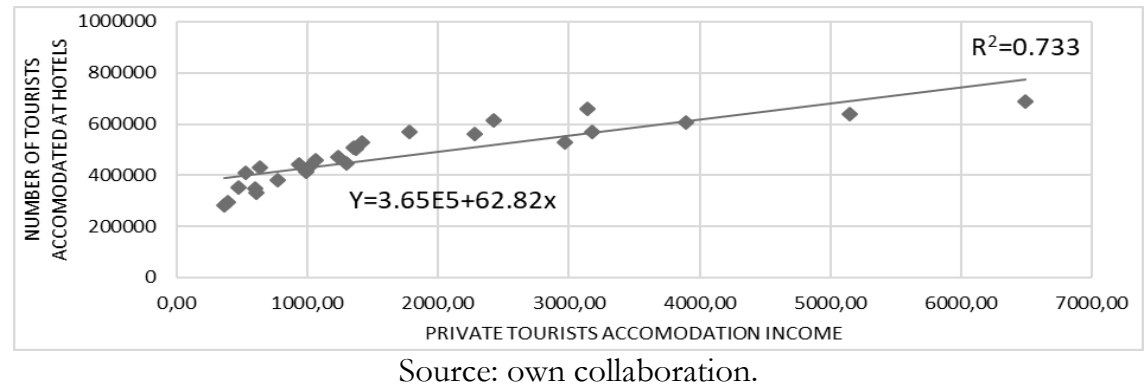

The results of linear regression analysis show that with the increase of 1 tourist staying at private accommodation, the number of tourists staying at hotels increases by an average of 4.5 tourists. Each additional stay in a private tourist accommodation increases the number of hotel tourists by an average of 1.51 tourists.

Figure 5. Linear regression (monthly data) of the number of hotel tourists and the number of nights spent in private accommodation.

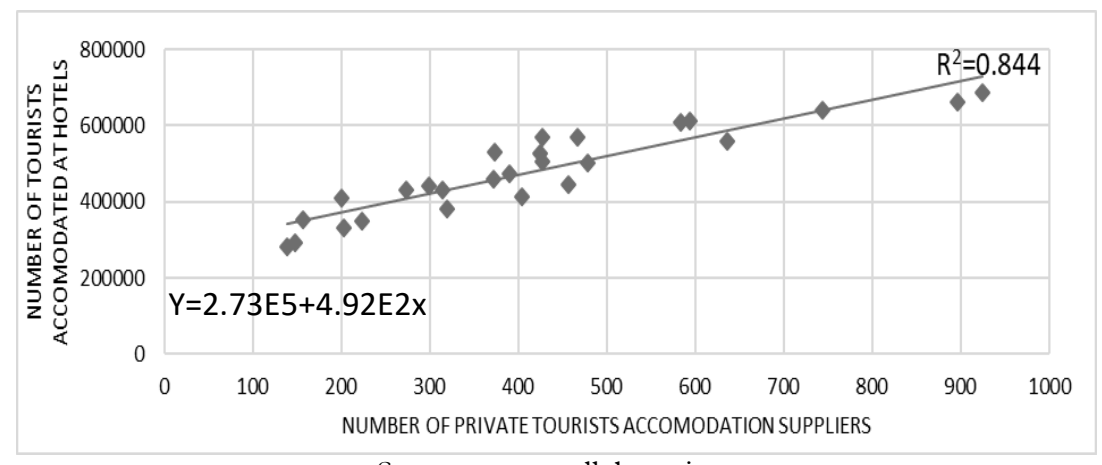

Source: own collaboration.

Based on the analysis of monthly data, it can be stated that private tourist accommodation does not have a statistically significant negative effect on the number of tourists staying in Lithuanian hotels. This may mean that in Lithuania the sharing economy in the accommodation sector is geared towards a different market for tourists than hotels and as a result these two players may be considered as noncompetitors.

The impact of the sharing economy on the number of hotel tourists is also tested by using the Quarterly 2012-2018 data. 
The dependent variable corresponds to the normal distribution, and the asymmetry and excision coefficients of all regressors are from zero, suggesting that their data are abnormally distributed (Table 6). Also, all regressors have exclusions that need to be removed. After eliminating the exceptions, the asymmetry and excision coefficients are shown in Table 7.

Table 6. Asymmetry and excision coefficients for quarterly data

\begin{tabular}{|l|c|c|}
\hline & Skewness & Kurtosis \\
\hline Number of tourists staying at hotels & 0.307 & -0.520 \\
\hline Private tourist accommodation provided overnight stays. & 1.520 & 1.374 \\
\hline Number of tourists at private tourist accommodation & 1.588 & 1.877 \\
\hline Income from private tourist accommodation & 1.620 & 1.835 \\
\hline Number of private tourist accommodation providers & 1.248 & 1.157 \\
\hline Number of private tourist accommodation establishments & 1.331 & 2.601 \\
\hline
\end{tabular}

Source: own collaboration.

Table 7. Asymmetry and Excess ratios after exclusions (quarterly data)

\begin{tabular}{|l|c|c|}
\hline & Skewness & Kurtosis \\
\hline Private tourist accommodation provided overnight stays. & 1.331 & 1.671 \\
\hline Number of tourists in private tourist accommodation & 1.278 & 1.141 \\
\hline Income from private tourist accommodation & 1.382 & 1.513 \\
\hline Number of private tourist accommodation providers & 0.831 & 0.773 \\
\hline
\end{tabular}

Source: own collaboration.

The Shapiro-Wilk test results (Table 8) confirm that the variables: number of tourists staying at hotels, number of private tourist accommodation providers and number of private tourist's accommodation places have a normal distribution ( $\mathrm{p}>0.05)$. As the coefficients of asymmetry and excision of other variables are between -2 and +2 , so they also correspond to the normal distribution (D. George, P. Mallery, 2010).

Table 8. Shapiro-Wilk test for quarterly data

\begin{tabular}{|l|c|c|c|}
\hline \multirow{2}{*}{} & \multicolumn{3}{|c|}{ Shapiro-Wilk } \\
\cline { 2 - 4 } & Statistic & $\mathrm{df}$ & $\mathrm{p}$ \\
\hline Number of tourists staying at hotels & 0.975 & 25 & 0.783 \\
\hline Income from private tourist accommodation & 0.847 & 25 & 0.002 \\
\hline Number of private tourist accommodation providers & 0.943 & 25 & 0.176 \\
\hline Private tourist accommodation provided overnight stays & 0.879 & 25 & 0.012 \\
\hline Number of tourists in private tourist accommodation & 0.875 & 25 & 0.005 \\
\hline
\end{tabular}

Source: own collaboration.

Correlation analysis shows that all variables correlate statistically significantly ( $p<0.05)$. Quarterly data-dependent variable, as well as monthly data, strongly correlated $(r>0.7)$ with all variables, making them a good fit for the regression model. The correlation analysis of quarterly data also shows that there is a positive relationship between the number of hotel tourists and all variables reflecting the sharing economy. It can be assumed that due to the differences in the nature of the services offered, there is no direct competition between Lithuanian hotels and private tourist accommodation and that their relationship is more complex than it seems. 
Linear regression analysis using quarterly data gave similar results as the annual data. Each additional tourist stays an average of 4.5 (4.1 on an annual basis) tourists staying at hotels. Each additional overnight stay in private tourist accommodation increases the number of hotel tourists by an average of 2.5 tourists (1.51 on an annual basis). With an increase in private tourist accommodation income of a thousand euros, the average number of tourists staying at hotels increases by 62.82 tourists, and each additional private accommodation provider increases by 492.1 tourists on average. Analysis of these data also suggests that private tourist accommodation does not have a statistically significant negative effect on the number of tourists staying in Lithuanian hotels.

It is also important to check whether the sharing economy can reduce the revenue generated by hotel accommodation services.

Year 2012-2018 quarterly data is used for hotel revenue analysis. Private tourist accommodation data is used after exclusion. Before carrying out the correlation and regression analysis, it is necessary to check that the dependent variable - hotel revenue for accommodation services corresponds to the normal distribution. The asymmetry factor for this variable is 0.601 , and -0.181 of the excision, since they are close to zero, it can be assumed that the variable is normally distributed.

The Shapiro-Wilk test (Table 9) confirms that hotel revenue for accommodation services has a normal distribution ( $\mathrm{p}>0.05)$ and is therefore suitable for regression analysis.

Table 9. Shapiro-Wilk test of hotel revenue for accommodation

\begin{tabular}{|l|c|c|c|}
\hline & \multicolumn{3}{|c|}{ Shapiro-Wilk } \\
\cline { 2 - 4 } & Statistic & $\mathrm{df}$ & $\mathrm{p}$ \\
\hline Hotel revenue from accommodation services & 0.959 & 28 & 0.322 \\
\hline
\end{tabular}

Source: own collaboration.

Correlation analysis revealed that hotel revenue for accommodation services is statistically significantly $(\mathrm{p}<0.01)$ correlated with all variables. All correlations are strong $(r>0.7)$ and positive. This indicates that the private accommodation of tourists does not adversely affect the revenue of Lithuanian hotels for accommodation services.

The results of the regression analysis, where the dependent variable is the hotel revenue for the accommodation provided, are shown in Figures 6-9.

Figure 6. Linear regression of hotel revenue from accommodation services and private tourist accommodation income (quarterly data)

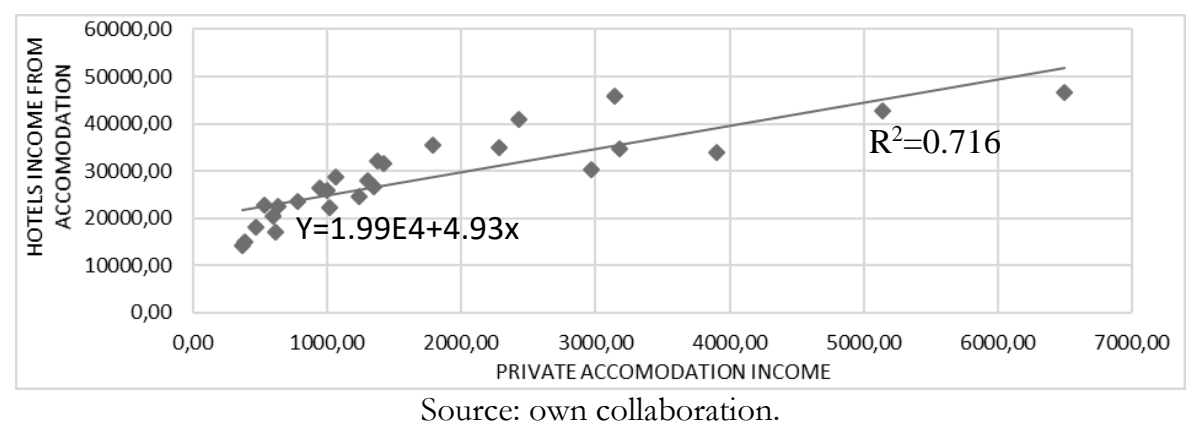

According to the results of the regression analysis of the quarterly data, each additional thousand euros in private tourist accommodation increases hotel revenue by an average of 4.93 thousand Eur. Each additional private tourist accommodation provider increases hotel revenue by an average of 40.42 thousand Eur. Providing one additional overnight stay for private tourists increases hotel revenue by an average of 0.19 thousand Eur. While one tourist stay with private persons increases the income of hotels 
by 0.33 thousand Eur. Thus, the sharing economy does not adversely affect the revenue of Lithuanian hotels.

Figure 7. Linear regression of hotel revenue from accommodation services and number of private tourist accommodation providers (quarterly data)

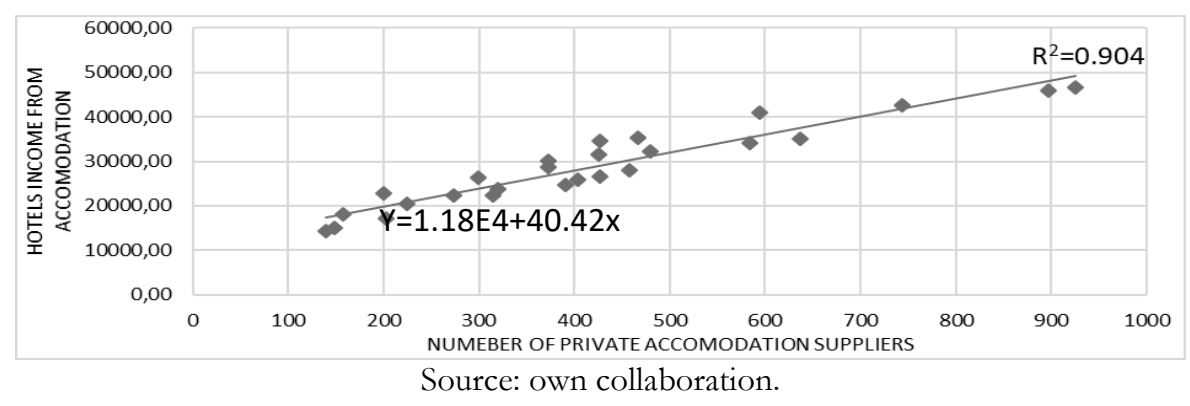

Figure 8. Linear regression of hotel revenue from accommodation and private accommodation

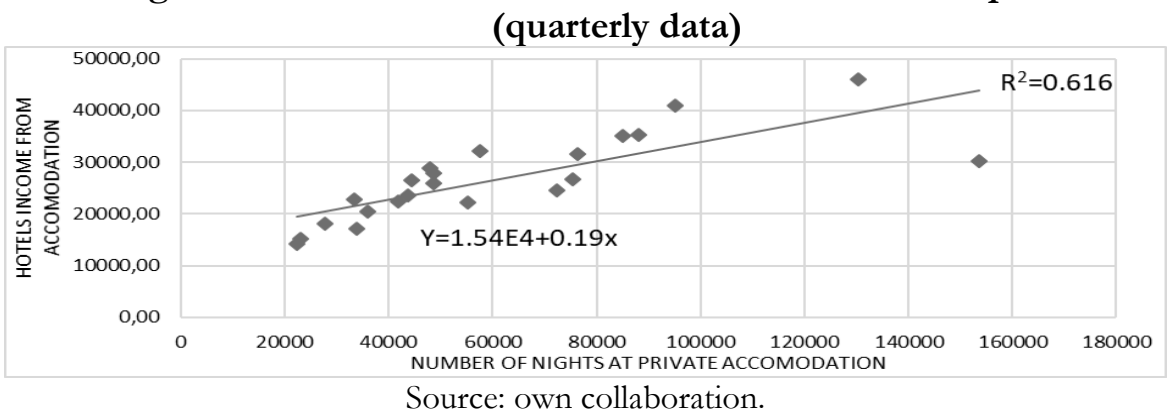

Figure 9. Linear regression of hotel revenue on accommodation services and number of tourists in private accommodation (quarterly data)

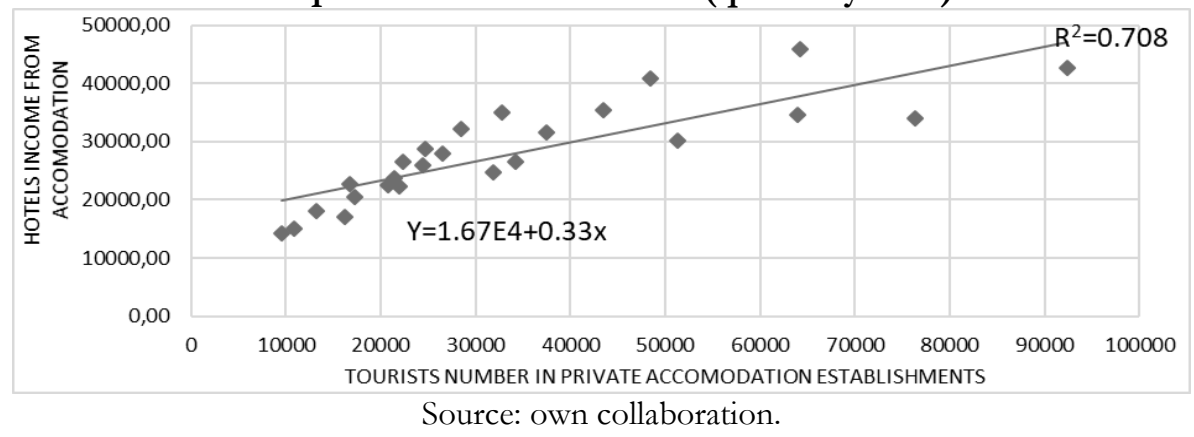

The impact of the sharing economy on hotel revenue from accommodation services was also tested using annual data.

Table 10. Asymmetry and excision coefficients for annual data

\begin{tabular}{|l|c|c|}
\hline & Skewness & Kurtosis \\
\hline Hotel revenue from accommodation services & 0.494 & -0.374 \\
\hline Income from private tourist accommodation & 1.065 & 0.280 \\
\hline Number of private tourist accommodation providers & 1.385 & 1.012 \\
\hline Private tourist accommodation provided overnight stays. & 0.598 & -0.983 \\
\hline Number of tourists in private tourist accommodation & 0.798 & -0.468 \\
\hline
\end{tabular}


All variables are close to the normal distribution (Table 10), except for the number of private tourist accommodation providers, which has an exception that needs to be removed. After eliminating the exceptions of this variable, its coefficients of asymmetry (1.382) and excess (1.362) changed slightly.

The Shapiro-Wilk test results (Table 11) show the normal distribution of most data ( $p>0.05$ ), and since the asymmetry and excision coefficients between number of private accommodation providers and private tourist accommodation income correspond to normality $(-2$ to +2$)$, they are also suitable for further analysis.

Table 11. Shapiro-Wilk test for annual data

\begin{tabular}{|l|c|c|c|}
\hline \multirow{2}{*}{} & \multicolumn{2}{|c|}{ Shapiro-Wilk } \\
\cline { 2 - 4 } & Statistic & $\mathrm{df}$ & $\mathrm{p}$ \\
\hline Hotel revenue from accommodation services & 0.967 & 16 & 0.796 \\
\hline Number of private tourist accommodation providers & 0.844 & 16 & 0.011 \\
\hline Number of tourists in private tourist accommodation & 0.907 & 16 & 0.104 \\
\hline Private tourist accommodation provided overnight stays. & 0.905 & 16 & 0.097 \\
\hline Income from private tourist accommodation & 0.885 & 16 & 0.046 \\
\hline
\end{tabular}

Source: own collaboration.

The correlation analysis of annual data also shows a statistically significant $(\mathrm{p}<0.01)$ correlation between hotel revenue for accommodation services and private tourist accommodation. The relationship between these variables is also positive and very strong ( $r>0.9)$. This correlation is the strongest compared to the previous correlation analysis, which once again confirms that the sharing economy, at least for the time being, does not adversely affect the Lithuanian hotel business.

The results of regression analysis using annual data, where the dependent variable is hotel revenue from accommodation services, are shown in Figures 10-13.

\section{Figure 10. Linear regression of hotel income from accommodation services and private tourist} accommodation income (annual data)

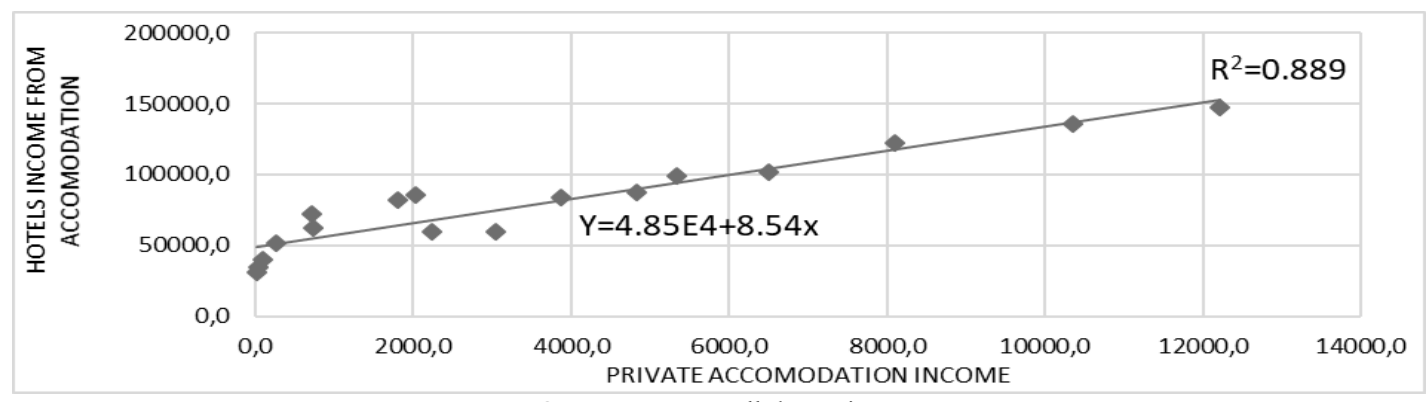

Source: own collaboration.

The regression analysis of the annual data does not show that the sharing economy is limiting hotels revenue in Lithuania.

Number occupancy rate directly shows how many rooms were rented. Hotel room occupancy rates are subject to change due to the sharing economy. Anticipating changes in this indicator is critical to planning and decision-making, as demand forecasting allows managers to plan inventory, workforce, supply, budget, and pricing accordingly to maximize revenue and minimize costs. For these reasons, it is important to check whether the sharing economy has an impact on this indicator. 
JOURNAL OF TOURISM AND SERVICES

Issue X, volume X, ISSN 1804-5650 (Online)

www.jots.cz

Figure 11. Linear regression of hotel income on accommodation services and number of private tourist accommodation providers (annual data)

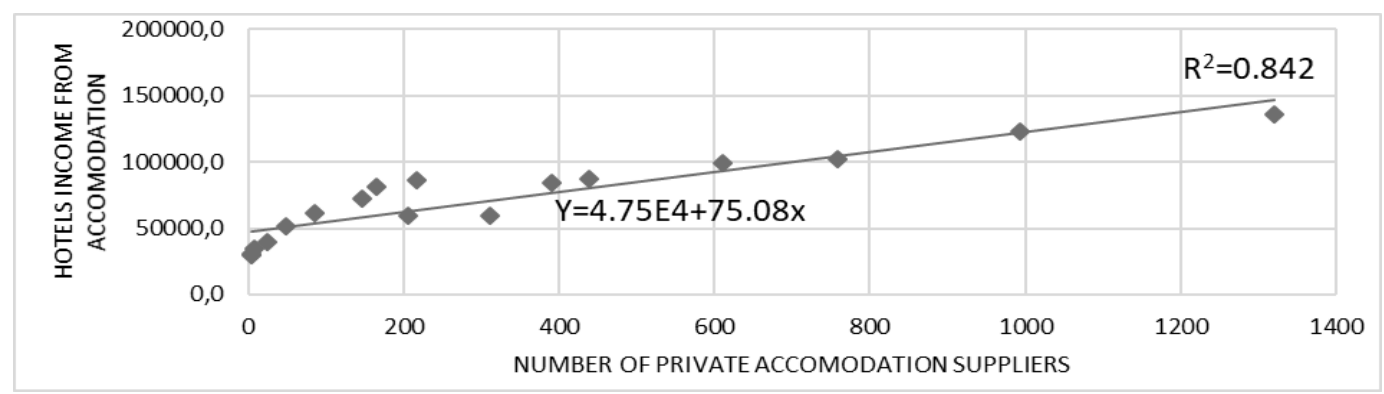

Source: own collaboration.

Figure 12. Linear regression of hotel revenue on accommodation and private accommodation (annual data)

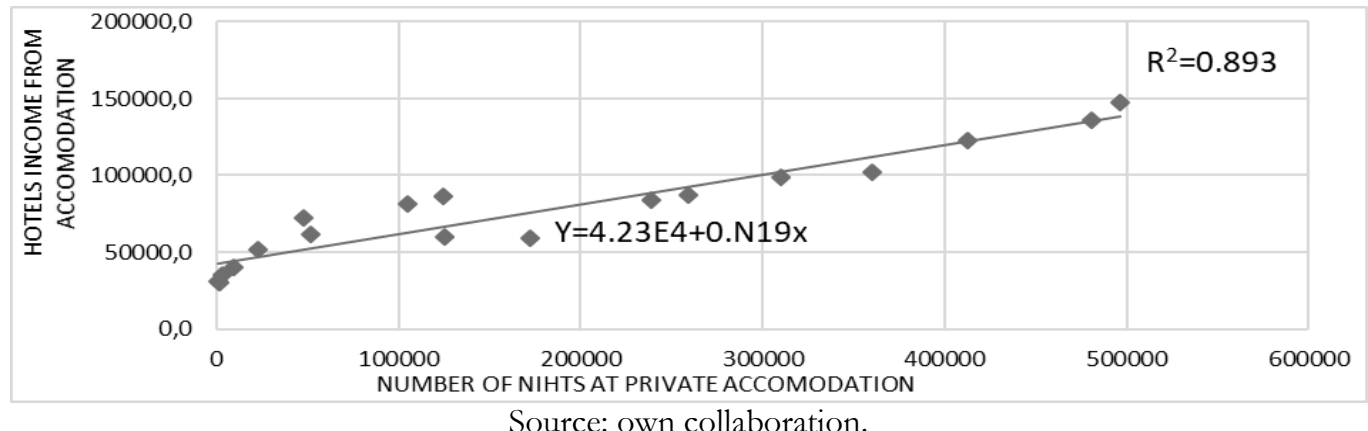

Monthly data for 2012-2018 is used for this analysis. data. The coefficient of asymmetry is 0.301 and that of the excision is -0.922 , which indicates that the data are close to normal distribution. The Kolmogorov-Smirnov test (Table 12) also confirms that the variable has a normal distribution ( $\mathrm{p}>0.05)$.

Figure 13. Linear regression of hotel income on accommodation services and number of tourists in private accommodation (annual data)

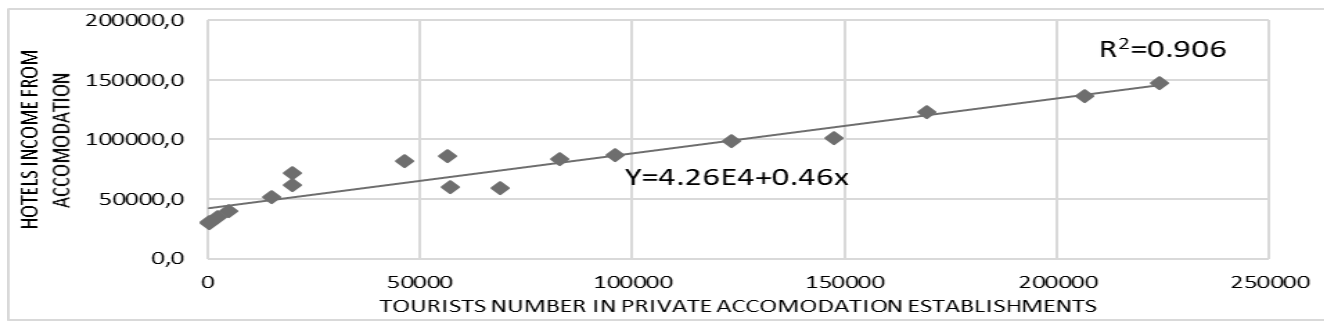

Source: own collaboration.

Table 12. Kolmogorov-Smirnov test for hotel room occupancy

\begin{tabular}{|l|c|c|c|}
\hline \multirow{2}{*}{} & \multicolumn{3}{|c|}{ Kolmogorov-Smirnov } \\
\cline { 2 - 4 } & Statistic & df & $\mathrm{p}$ \\
\hline Hotel room occupancy & 0.093 & 73 & 0.199 \\
\hline
\end{tabular}

The results of the correlation analysis are presented in Table 13. Hotel room occupancy correlates with private tourist accommodation rates statistically significant $(p<0.01)$. The correlation coefficient is 
positive and shows a strong relationship between the variables $(r>0.7)$. Such results may indicate that the tourist accommodation market is large enough for two players and that they are complementary.

Table 13. Correlation between hotel occupancy rates and regressors

\begin{tabular}{|c|c|c|c|c|}
\hline & & $\begin{array}{l}\text { Number of tourists } \\
\text { staying in hotels }\end{array}$ & $\begin{array}{l}\text { Private tourist } \\
\text { accommodation } \\
\text { provided overnight } \\
\text { stays }\end{array}$ & $\begin{array}{l}\text { Number of } \\
\text { tourists in private } \\
\text { tourist } \\
\text { accommodation }\end{array}$ \\
\hline \multirow[t]{3}{*}{$\mathrm{r}$} & Hotel room occupancy & 1.000 & 0.798 & 0.885 \\
\hline & $\begin{array}{l}\text { Private tourist accommodation } \\
\text { provided overnight stays. }\end{array}$ & 0.798 & 1.000 & 0.960 \\
\hline & $\begin{array}{l}\text { Number of tourists in private } \\
\text { tourist accommodation }\end{array}$ & 0.885 & 0.960 & 1.000 \\
\hline \multirow[t]{3}{*}{$\mathrm{p}$} & Hotel room occupancy & . & 0.000 & 0.000 \\
\hline & $\begin{array}{l}\text { Private tourist accommodation } \\
\text { provided overnight stays. }\end{array}$ & 0.000 & . & 0.000 \\
\hline & $\begin{array}{l}\text { Number of tourists in private } \\
\text { tourist accommodation }\end{array}$ & 0.000 & 0.000 & 0.000 \\
\hline
\end{tabular}

Source: own collaboration.

The results of the regression analysis are shown in Figures 14 and 15.

Figure 14. Linear regression of hotel occupancy rates and number of overnight stays provided by private tourist accommodation

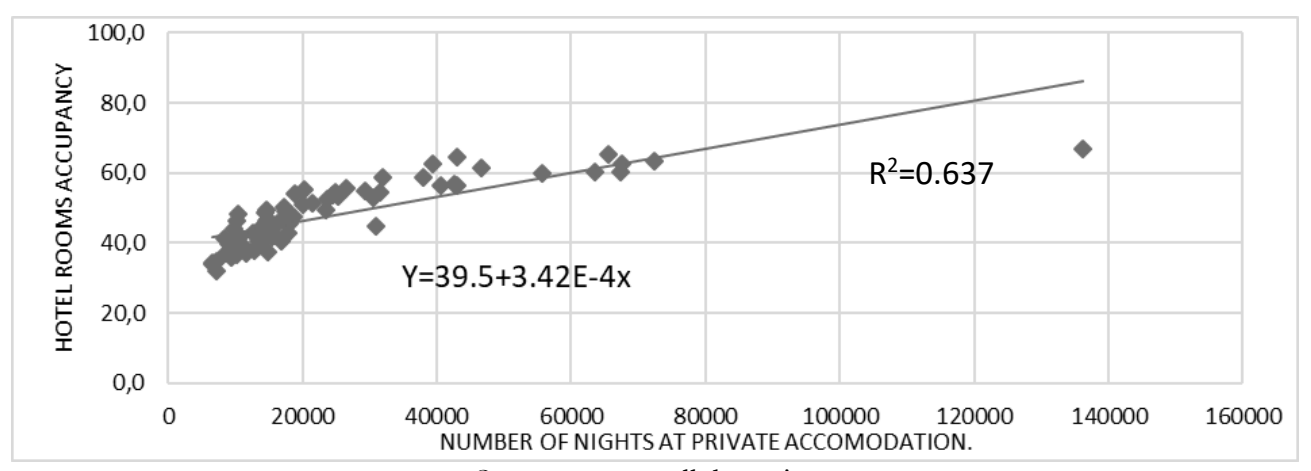

Source: own collaboration.

Regression analysis revealed that hotel accommodation occupancy has a very little effect on private tourist accommodation. Each additional tourist accommodation at private accommodation has a very small impact on hotel occupancy, close to zero. For each additional private individual, hotel occupancy increases by 0.001 percent. Although the impact on hotel occupancy is very small, it still shows that private tourist accommodation does not adversely affect occupancy of Lithuanian hotel rooms.

To sum up the evaluation of the impact of the sharing economy on the hotels business, the sharing economy does not adversely affect the Lithuanian hotel business, all hypotheses were not confirmed. Correlation regression analysis shows a positive relationship between the sharing economy and the number of hotel tourists, hotel revenue from accommodation activities, and hotel room occupancy. Such results may have been due to a variety of reasons:

1. The market share of the sharing economy is still very small. The result is rather linked to the general growth of tourists in the market. 
2. The sharing economy and Lithuanian hotels do not compete but target different customers. The sharing economy does not take away the market share from the hotels but attracts a new customer segment. Research results suggest that clients in the sharing economy are different from the traditional hotel guest, i.e. they might not have visited the country if the prices would not be suitable.

\section{Figure 15. Linear regression graph of hotel occupancy rates and number of tourists accommodated in private accommodation}

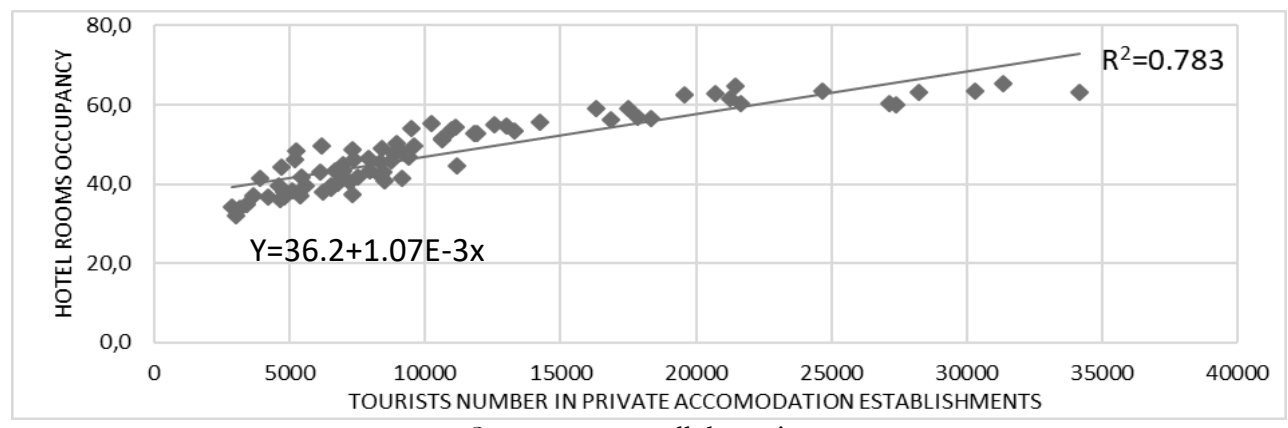

Source: own collaboration.

\section{Conclusion}

The sharing economy is the phenomenon of sharing underutilized assets and services through information technology usage. The leased goods and services are owned solely by the consumer, which is the biggest difference compared to the traditional market. The sharing economy brings economic benefits to its participants, it also increases competition that leads to lower prices, entrepreneurship, innovation, sustainability.

The sharing economy in the accommodation industry can be considered as a major driver of hotel demand. The sharing economy is threatening traditional hotels. It is expected to negatively impact hotel revenue, change traditional hotel and guest behaviour.

Statistical analysis shows improving performance of Lithuanian accommodation business. The sharing economy sector is growing much faster than hotels businesses, but its market share is still very small. All hypotheses were not confirmed. Sharing economy does not negatively impact on hotel business KPIs (number of customers, rooms occupancy, revenue). The correlation and regression analyses revealed a positive impact on hotel business. However, as the sharing economy has a very small market share, the link is associated with the general growth of tourism. Correlation and regression analyses reveal the ratio in which number of tourists increases in both sectors.

\section{References}

1. Airbnb. (2013). Airbnb Launches New Disaster Response Tool. Retrieved October 20, 2019, from https://www.airbnb.com/press/news/airbnb-launches-new-disaster-response-tool

2. Airbnb. (2014). New Study Reveals A Greener Way to Travel: Airbnb Community Shows Environmental Benefits of Home Sharing (EU). Retrieved October 20, 2019, from https://www.airbnb.dk/press/news/new-study-reveals-a-greener-way-to-travel-airbnbcommunity-shows-environmental-benefits-of-home-sharing-eu 


\section{JOURNAL OF TOURISM AND SERVICES}

Issue X, volume X, ISSN 1804-5650 (Online)

www.jots.cz

3. Alaerds, R., Grove, S., Besteman, S., Bilderbeek, P. (2017). The Foundations of our Digital Economy. Structure Study, 2017 (Year: 1, Issue: 1). Retrieved October 20, 2019, from https://www.dhpa.nl/wp-content/uploads/2017/04/Foundations_Digital_Econo my.pdf

4. Androniceanu, A. (2019). The social sustainability of smart cities: urban technological innovation, big data management, and the cognitive internet of things. Geopolitics, History, and International Relations 11(1), 110-115. doi:10.22381/GHIR11120197

5. Androniceanu, A., Tvaronavičienè, M. (2019). Developing a holistic system for social assistance services based on effective and sustainable partnerships. Administratie si Management Public, 33, 103-118. doi: 10.24818/amp/2019.33-06.

6. Anyakoha, C. (2019). Job analysis as a tool for improved organizational performance of SMEs in Lagos, Nigeria. Central European Journal of Labour Law and Personnel Management, 2 (1), 7-16. doi: 10.33382/cejllpm.2019.02.01

7. Barron, K., Kung, E., Proserpio, D. (2018). The Sharing Economy and Housing Affordability: Evidence from Airbnb. SSRN Electronic Journal. doi: https://doi.org/10.1145/3219166.3219180

8. Belás, J., Khan, K.A., Maroušek, J., \& Rozsa, Z. (2020). Perceptions of the importance of business ethics in SMEs: A comparative study of Czech and Slovak entrepreneurs. Ethics \& Bioetics (in Central Europe), 10(1-2), 96-106. doi: 10.2478/ebce-2020-0010.

9. Bekešienè, S. (2015). Duomenu analizès SPSS pagrindai. Generolo Jono Žemaičio Lietuvos karo akademija. Retrieved October 20, 2019, from http://www.lka.lt/lt/mokslineveikla/leidiniai/vadoveliai/download.htmlid=986;pdf_id=37368

10. Bergh, A., Funcke, A., Wernberg, J. (2018). Timbro sharing economy index. Timbro. Retrieved October 20, 2019, from https://timbro.se/app/uploads/2018/07/tsei-version-17_web.pdf

11. Bhise, S., Singh, K. R. (2016). Sharing Economy-A new way of consumption in general and in India. $\quad$ Retrieved October 20, 2019, from https://www.researchgate.net/profile/Rajnikant_Singh2/publication/320299599_Title_Sharin g_Economy-A_new_way_of_consumption_in_general_and_in_India_Discipline-

Marketing_Sub-theme-

Sustainable_Marketing_Strategies/links/59dcaebf0f7e9b146003a83e/Title-Sharing-EconomyA-new-way-of-consumption-in-general-and-in-India-Discipline-Marketing-Sub-theme-

Sustainable-Marketing-Strategies.pdf

12. Biswas, R., Pahwa, A., Sheth, M. (2015). The rise of the sharing economy. The Indian landscape. Ernst\&Young LLP. Retrieved October 20, 2019, from http://sharehub.kr/wpcontent/uploads/2015/11/e1a7c1d73dfae19dcfa0.pdf

13. Botsman, R. (2015). Defining the Sharing Economy: What Is Collaborative Consumption And What Isn't? Retrieved October 20, 2019, from https://www.fastcompany.com/3046119/defining-the-sharing-economy-what-is-collaborativeconsumption-and-what-isnt

14. Brauckmann, S. (2017). City tourism and the sharing economy - potential effects of online peer-to-peer marketplaces on urban property markets. Journal of tourism futures. Vol. 3 no. 2, pp. 114-126. doi: https://doi.org/10.1108/JTF-05-2017-0027

15. Čekanavičius, V., Murauskas, G. (2014). Taikomoji regresine analize socialininose tyrimuose. Vilniaus universiteto leidykla. Retrieved October 20, 2019, from http://www.statistika.mif.vu.lt/wpcontent/uploads/2014/04/regresine-analize.pdf

16. Chafkin M. 2016. Airbnb opens the world. FastCompany.com. Retrieved October 20, 2019, from http://www.fastcompany.com/3054873/can-airbnb-unite-the-world

17. Ciarniene, R., Vienazindiene, M., Vojtovic, S. (2017). Process Improvement for Value Creation: a Case of Health Care Organization. Inzinerine Ekonomika-Engineering Economics. Vol. 28, Issue 1, pp. 79-87. https://doi.org/10.5755/j01.ee.28.1.16601 


\section{JOURNAL OF TOURISM AND SERVICES}

Issue X, volume X, ISSN 1804-5650 (Online)

www.jots.cz

18. Constantiou, I., Marton, A., Tuunainen, V. K. (2017). Four Models of Sharing Economy Platforms. MIS Quarterly Executive. Retrieved October 20, 2019, from https://pdfs.semanticscholar.org/58ac/3edfce5d1aa8e185dbaf1159ca8b3a63c852

19. Das, S. (2018). Sharing Economy. Wilmott Magazine. Volume 93. Retrieved October 20, 2019, from https://www.fixedincomeforum.com.au/wp-content/uploads/sites/7/2017/ 07/Sharingeconomy.pdf

20. Denver Bike Sharing. (2017). 2017 Annual Report. Retrieved October 20, 2019, from http://denver.bcycle.com/docs/librariesprovider34/default-documentlibrary/dbs_annualreport_2016_05.pdf?sfvrsn=2

21. Dkhili, H. (2018). Environmental performance and institutions quality: evidence from developed and developing countries. Marketing and Management of Innovations, (3), 333-344. https://doi.org/10.21272/mmi.2018.3-30

22. Felländer, A., Ingram, C., Teigland, R. (2015). The sharing economy: embracing change with caution. Entreprenörskapsforum, ISBN: 978-91-89301-75-7. Retrieved October 20, 2019, from https://www.academia.edu/download/37923227/Sharing-Economy_webb. pdf

23. Grampp, M., Zobrist, L., Abegg, A. (2016). The sharing economy in Switzerland: Do we need more, fewer, or new regulations. Deloitte. Retrieved October 20, 2019, from https://www2.deloitte.com/content/dam/Deloitte/ch/Documents/consumer-business/chen-cib-the-swiss-sharing-economy.pdf

24. Greasley, P. (2008). Quantitative Data Analysis Using SPSS: An Introduction for Health \& Social Science. Open University Press. doi: https://doi.org/10.1017/S1463423608 000790

25. Grybaitè, V., \& Stankevičienè, J. (2018). An empirical analysis of factors affecting sharing economy growth. Oeconomia Copernicana, 9(4), 635-654. https://doi.org/10.24136/oc.2018.031.

26. Henten, H. A., Windekilde, M. I. (2016). Transaction costs and the sharing economy. INFO. Vol. 18, Issue 1, pp. 1-15. Retrieved October 20, 2019, from https:// www.econstor.eu/bitstream/10419/ 127145/1/Henten-Winderkilde.pdf

27. Jašková, D. (2019). Assessment of social development in Slovakia in the context of human resources. Central European Journal of Labour Law and Personnel Management, 2 (2), 21-32. doi: 10.33382/cejllpm.2019.03.02

28. Jibril, A. B., Kwarteng, M. A., Appiah-Nimo, C., \& Pilik, M. (2019). Association rule mining approach: evaluating pre-purchase risk intentions in the online second-hand goods market. Oeconomia Copernicana, 10(4), 669-688. https://doi.org/10.24136/oc.2019.032.

29. Kasprowicz, T. (2016). The emergence and development of a sharing economy. 4liberty.eu Review No. 5. Retrieved October 20, 2019, from http://4liberty.eu/wpcontent/uploads/2016/10/Tomasz-Kasprowicz_The-Emergence-and-Development-of-aSharing-Economy_Review_5.pdf

30. Kiseláková, D., Šofranková, B., Onuferová, E., \& Čabinová, V. (2019). The evaluation of competitive position of EU-28 economies with using global multi-criteria indices. Equilibrium. Quarterly Journal of Economics and Economic Policy, 14(3), 441-462. https://doi.org/10.24136/eq.2019.021.

31. Ključnikov, A., Krajč́k, V., Vincúrová, Z. (2018). International Sharing Economy: the Case of AirBnB in the Czech Republic. Economics and Sociology, 11(2), 126-137. doi: 10.14254/2071789X.2018/11-2/9

32. Ključnikov, A., Civelek, M., Čech, P. \& Kloudová, J. (2019). Entrepreneurial orientation of SMEs' executives in the comparative perspective for Czechia and Turkey. Oeconomia Copernicana, 10(4), 773-795. doi: 10.24136/oc.2019.035

33. Ključnikov, A., Civelek, M., Krajcik, V., \& Kmeco, L. (2020). Innovations in Tourism Marketing: Sharing Economy Platform. Marketing and Management of Innovations, 1, 11-25. doi: http://doi.org/10.21272/mmi.2020.1-01 


\section{JOURNAL OF TOURISM AND SERVICES}

Issue X, volume X, ISSN 1804-5650 (Online)

www.jots.cz

34. Lithuanian competition council. (2016). Dalijimosi ekonomika: paskata konkurencijai ir iššūkis reguliavimui. Konkurencijos tarybos naujienlaiškis nr. 22. Retrieved October 20, 2019, from https://kt.gov.lt/lt/naujienos/dalijimosi-ekonomika-paskata-konkurencijai-ir-issukisreguliavimui

35. Malhotra, A., Alstyne, M. (2014). Economic and Business Dimensions: The Dark Side of the Sharing Economy and How to Lighten It. Viewpoints, Vol. 57, No. 11. doi: 101145/2668893

36. Mészáros, M. (2018). Employing of self-employed persons. Central European Journal of Labour Law and Personnel Management, 1 (1), 46 - 67. doi: http:/ /doi.org/ 10.33382/cejllpm.2018.01.04

37. Mikołajczak, P. (2019). Becoming business-like: the determinants of NGOs' marketization turning into social enterprises in Poland. Oeconomia Copernicana, 10(3), 537-559. https://doi.org/10.24136/oc.2019.026.

38. Mura, L., Marchevska, M., Dubravska, M. (2018). Slovak Retail Business Across Panel Regression Model. Marketing and Management of Innovations, 4, pp. 203-211.

doi: http://doi.org/10.21272/mmi.2018.4-18

39. Mura, L., Kajzar, P. (2019). Small Businesses in Cultural Tourism in a Central European Country. Journal of Tourism and Services, Vol. 10, No. 19, pp. 40-54. doi: https://doi.org/10.29036/jots.v10i19.110

40. MuniRent. (2019). What is MuniRent? Retrieved October 20, 2019, from https:// www.munirent.co/about

41. Muñoz, P., Cohen, B. (2018). A Compass for Navigating Sharing Economy Business Models. California Management Review. Vol. 61(1), pp. 114-147.

doi: https://doi.org/10.1177/0008125618795490

42. Navickas, V., Vojtovic, S., Svazas, M. (2017). Biomass Clusters Influence on Business Competitiveness. Polish Journal of Management Studies. Vol. 16, Issue 2, pp. 188-197. doi: 10.17512/pjms.2017.16.2.16

43. Nosková, M., Peráček, T. (2019). Termination of employment in the Slovak Republic as a key issue of HR Management. Central European Journal of Labour Law and Personnel Management, 2 (2), 44-59. doi: 10.33382/cejllpm.2019.03.04

44. OECD. (2018). Tourism Trends and Policies 2018. OECD Publishing, Paris. Retrieved October 20, 2019, from https://www.oecd.org/cfe/tourism/2018-Tourism-Trends-Policies-HighlightsENG.pdf

45. Oskam, J., Boswijk A. (2016). Airbnb: the future of networked hospitality businesses. Journal of Tourism Futures. Vol. 2, no. 1, pp. 22-42. doi: https://doi.org/10.1108/JTF-11-2015-0048

46. Pais, I., Provasi, G. (2015). Sharing Economy: A Step towards the Re-Embeddedness of the Economy? Stato e mercato, pp. 347-378. Retrieved October 20, 2019, from https://www.rivisteweb.it/doi/10.1425/81604

47. Peerby. (2018). What is Peerby? Retrieved October 20, 2019, from https:// peerby.desk.com/customer/en/portal/articles/1497031-what-is-peerby-

48. Petropoulos, G. (2017). An economic review of the collaborative economy. Policy Contribution, Issue n. 5. 2017. Retrieved October 20, 2019, from http://hdl.handle.net/10419/173101

49. PricewaterhouseCoopers. 2015. Sharing or paring? Growth of the sharing economy. Retrieved October 20, 2019, from https://www.pwc.com/hu/en/kiadvanyok/assets/ pdf/sharingeconomy-en.pdf

50. Ranchordás, S. (2016). Sharing Economy: New Rules for New Times. IESEinsight, issue 30 third quarter. Retrieved October 20, 2019, from https://www.ieseinsight.com/ fichaMaterial.aspx? $\mathrm{pk}=134894$ \&idi $=2 \&$ origen $=1$

51. Skackauskiene, I., Vilkaite-Vaitone, N., Vojtovic, S. (2015). Model for Measuring Customer Loyalty Towards a Service Provider. Journal of Business Economics and Management. Vol. 16, Issue 6, pp. 1185-1200. doi: 10.3846/16111699.2015.1112829 
52. Statistics Lithuania. (2018). Transportas ir ryšiai 2017. Vilnius. Retrieved October 20, 2019, from https://osp.stat.gov.lt/services-portlet/pub-edition-file?id $=31500$

53. Statistics Lithuania. (2020). Number of accommodation establishments. Retrieved October 20, 2019, from https://osp.stat.gov.lt/

54. Šmskis, D. (2016). Sharing economy in Lithuania: lessons of success and failure. 4liberty.eu Review No. 5. Retrieved October 20, 2019, from http://4liberty.eu/wpcontent/uploads/2016/10/Dominykas-Sumskis_Sharing-Economy-in-Lithuania-Lessons-ofSuccess-and-Failure_Review_5.pdf

55. World bank Group. (2018). Tourism and the Sharing Economy: Policy \& Potential of Sustainable Peer-to-Peer Accommodation. Retrieved October 20, 2019, from http://documents.worldbank.org/curated/en/161471537537641836/pdf/130054-REVISEDTourism-and-the-Sharing-Economy-PDF.pdf

56. Vasylieva, T. A., Lieonov, S. V., Makarenko, I. O., \& Sirkovska, N. (2017). Sustainability information disclosure as an instrument of marketing communication with stakeholders: markets, social and economic aspects. Marketing and Management of Innovations, (4), 350-357. https://doi.org/10.21272/mmi.2017.4-31

57. Zipcar. (2013). Croydon council cuts employee car usage in half with zipcar. Retrieved October 20, 2019, from http://www.zipcar.co.uk/press/releases/croydon-council-cuts-employee-carusage-in-half-with-zipcar

\section{Brief description of Author/Authors:}

\section{Paulína Srovnalíková, Ing. PhD., MBA}

Department of Management and Human Resource Development, Faculty of Social and Economic Relations, Lecturer in Personal and Payroll legislation. Študentská 3, 91150 Trenčín, Slovakia. E-mail: paulina.srovnalikova@tnuni.sk. Scientific interests: Alternative forms of Entrepreneurship, Sharing economy, Family businesses.

\section{Evelina Semionovaitè}

UAB KPMG Baltics, Klaipeda, Lithuania, Audit assistant. Url: home.kpmg, email: semionovaite2@gmail.com. Scientific interests: Sharing economy.

\section{Edita Baranskaitè}

Department of Economics, Faculty of Social Sciences and Humanities, Klaipèda University, Klaipèda, Lithuania, PhD student. Url: www.ku.lt, e-mail: edita.baranskaite@ku.lt. Scientific interests: Tourism innovations economic impact.

\section{Daiva Labanauskaitė, PhD}

Department of Economics, Faculty of Social Sciences and Humanities, Klaipèda University, Klaipèda, Lithuania, Associate professor. Url:www.ku.lt, e-mail: labanauskaite.daiva@gmail.com. Scientific interests: Tourism; The economics of services. 